Tatjana Ivanović ${ }^{\star *}$, Sonja Ivančević ${ }^{2}$

${ }^{1}$ University of Belgrade, Faculty of Organizational Sciences, Serbia ²PrimarySchool 'Starina Novak', Belgrade, Serbia

\title{
Turnover Intentions and Job Hopping among Millennials in Serbia
}

DOI: 10.7595/management.fon.2018.0023

\begin{abstract}
:
Research Question: The purpose of this paper is to determine whether the number of jobs the Millennial generation intend to change during their career is larger than that of previous generations; to compare the Millennials' intention to leave their current job to the previous generations', and also to examine the relation between the Millennials' turnover intention and their job satisfaction. Motivation: Millennials keep their resumes updated and have a reputation to be job hoppers (Shaw \& Fairhurst, 2008; Meier \& Crocker, 2010). Moreover, their job hopping has been an unprecedented problem for the employers (Tulgan 2015) and they are reported to have a higher turnover intention rate than other generations (Kowske, Rasch \& Wiley 2013; Deloitte, 2011; Twenge, 2010; Sujansky \& Ferri-Reed, 2009). Additionally, it is generally accepted that job satisfaction and employee turnover intention are negatively related (Mobley 1977; Susskind et al. 2000; Schwepker 2001). Having in mind a lack of relevant literature as well as research in Eastern European countries, our goal was to explore whether the same can be concluded for the Millennials in Serbia. Idea: The core idea of this paper was to empirically evaluate the relationship between the stated variables. Data: The analysis was conducted during 2017 in Serbia using a questionnaire which was made in the form of an online survey and distributed by email and posted on social networking websites. A total of 802 valid responses were received. Tools: Statistical analyses of all collected data were used to draw conclusions. Findings: The results of the study confirmed that the intention of the respondents to change a larger number of jobs in their career increases as we move towards the youngest generation in the workplace. Generation $Y$ was found to be the only generation that has a higher percentage of those who think that they will quit the current job in the next two years than those who expect the opposite. The analysis confirmed that turnover intention increases with job dissatisfaction - the greater their job satisfaction is, the fewer Millennials will want to change their current employer in the next two years. Contribution: This paper expands existing research related to the turnover intentions and job hopping of Millennials and provides recommendations for organizations for retaining the members of Generation Y.
\end{abstract}

Keywords: Millennials, turnover intention, job hopping, job satisfaction.

JEL Classification: J24, J28, J63, M50

\section{Introduction}

Modern workplace consists of a multigenerational workforce, while members of each generation resemble each other. Influenced by various events that shaped their childhood and adolescence, they adopt the same system of beliefs, values, expectations and behavioral patterns that make them different from previous generations and form a recognizable generational identity (Inglehart, 1997).

The number of academics and practitioners aiming to explore the issues of generational diversity and intergenerational collaboration has increased significantly (Zhezhu et al., 2010), in order to help organizations identify the profiles of their employees. This should serve them to align their employees' needs and values with the organizational requirements (Singh, Raj and Bhandaker, 2012) and thus prevent their dissatisfaction, absenteeism and increased turnover rates.

The three generations comprise the current workplace/workforce: Baby Boomer Generation, Generation X and Generation $Y$ or the Millennial generation ( $\mathrm{Ng} \&$ Schweitzer, 2010). Almost all the members of the Silent Generation have retired, and the generation $Z$ has just begun to enter the workplace. 
According to multiple research, unlike the other generations, organizations seem to be particularly challenged concerning retaining the Millennials (Deal, Altman, \& Rogelberg, 2010; Ng \& Schweitzer, 2010). They spend a lot of time and money for their recruitment, training and retention, but the Millennials are leaving jobs earlier and more frequently than the previous generations (Meier \&Crocker, 2010; Twenge, 2010). Their job hopping has been an unprecedented problem and their integration into the business culture created by the Baby-Boomer generation has proved to be a difficult thing to do (Tulgan, 2015). For that reason, during the last two decades, numerous studies have been conducted to help organizations manage their unique characteristics (Hammill, 2005) and identify the Millennials' systems of values, aspirations, goals, priorities in life and lifestyle, preventing them to leave jobs so frequently (Singh, Raj and Bhandaker, 2012; Deal, Altman \& Rogelberg, 2010).

The results of some studies indicate that the Millennials in Serbia are relatively similar to their peers in other countries (e.g., Kovacevic \& Labrovic, 2018) as regards their general characteristics. However, there is still a lack of relevant literature as well as research on turnover intentions of the Millennials in Eastern European countries, particularly in Serbia.

With that in mind, the purpose of this study was to determine whether the number of jobs the Millennial generation intend to change during their career is larger than that of previous generations; to compare the Millennials' intention to leave their current jobs to the previous generations', and also to examine the relation between the Millennials' turnover intention and their job satisfaction/dissatisfaction.

The hypotheses established in the study were tested in the specific environment of Serbia - a country which is undergoing a transition process and the EU accession process as a candidate country. In general, a notable lack of relevant HRM literature and research is evident in developing countries, especially transition countries such as Serbia.

\section{Literature Review}

In order to grasp organisations' biggest challenge with the Millennial Generation - retention (Meier \&Crocker, 2010; Twenge, 2010) - we need to understand both the characteristics and factors that shaped the Millennials and the concepts of job hopping, turnover and turnover intentions, and finally the relation between job satisfaction and turnover intention.

Nevertheless, before describing the Millennials, it is necessary to mention two older generations they share their workplace with: Baby Boomer generation and Generation X.

Baby Boomers (1946-1964) is the oldest generation in the workplace, comprised of the members born after the Second World War in the era of extreme optimism, possibility and progress. This generation that created the workplace as it looks today is extremely committed to their work, disciplined and tries hard to reach their goals enjoying the rewards afterwards. They were not likely to change employers, sometimes staying with one company throughout their entire career (Zemke et al., 2000).

Generation X (1965-1979) grew up in the shadow of the massive generation of Baby Boomers (Zemke et al., 2000) and is twice smaller in number than the generations that came before and after them. They are selfsufficient, sceptical, well-educated and independent (Zemke et al., 2000), but remarkably adaptable to diverse experiences. Their communication is fast and direct; they do not like protocols, tend to have their work done and then commit to their families and private lives (Olson \& Brescher, 2011). The work-life balance is very important to this generation (Buzza, 2017), and so are flexible work arrangements (Ciarniene \& Vienazindiene, 2018).

\subsection{Millennials in the Workplace}

\subsubsection{Name and the Numbers of the Millennial Generation}

Generation $Y$ or the Millennial Generation is the youngest generation active in the workplace today. Most researchers and authors use a range between 1980 and 2000 to mark the birth years of the members of this generation. Other names for this generation are also in use, such as 'Nexters ' or 'Nextus Generation' (Barnard, 1998; Zemke, Raines, and Filipczak, 2013), 'Trophy kids', 'Internet Generation' or 'Txt Generation', or 'Boomerang ' or 'Peter Pan' generation, as they are called by the American sociologist Kathleen Shaputis (2004), because of the characteristics they have. According to the Pew research centre, in 2015, the Millennials made up 34 percent of the US labour force, and the same source anticipates that by 2020 they 
will make almost half (46 percent) of the workforce. Even more dramatic are the Brookings' numbers which claim that by 2025 Millennials will make 75 percent of the global workforce. It is worth noting that the Millennial population as a whole (not just its workforce) surpassed that of the Baby Boomer generation (1946-1965) in 2015.

\subsubsection{Factors that Shaped the Millennials}

In order to better understand this generation, we need to consider the main factors that shaped their childhood and growing up, namely: globalization, technology and digital environment, the uncertainty of institutions and diversity. Also, two micro trends that have formed the Millennials particularly stand out: helicopter parenting and virtual reality (Tulgan, 2015).

Millennials are the first generation born in the Internet age. They are called digital natives because they are native speakers of the digital language of computers, the Internet and other virtual reality media (Caraher, 2015). The advance of technology has made the world a 'global village'. The quality of somebody's work, not their geography, has become a many headhunters' priority. Meeting people virtually, travelling more internationally and connecting globally is what Millennials expect in their workplace, making diversity a must in their professional lives (Tulgan, 2015). Being raised and praised by overprotective helicopter parents, they need their managers to be their mentors who will guide them patiently through the business world, giving them feedback on a daily basis (Ivancevic \& Ratkovic, 2016).

Nevertheless, for this research, one last shaping factor is the most important - the uncertainty. The Generation $\mathrm{Y}$ is defined by uncertainty - the uncertainty of their safety, the uncertainty of their future, and the uncertainty of what is to come next. Terrorism, the global economic crisis, recession, layoffs, the massacres that took place in schools, the kidnapping of children and similar events, have all been their reality, highlighting the unpredictability of tomorrow. The only certain thing is that everything can change and that the change is actually the only certainty in their lives. And they have learned to expect it (Tulgan, 2015; Caraher, 2015; dos Reis, 2018).

\subsubsection{How the Millennials are Perceived in the Workplace}

Bearing that in mind, the whole concept of their career perspective has changed in comparison with one of the former generations. Lifelong learning, perpetual professional development and acquisition of new skills have strengthened and equipped them for the time of the utmost uncertainty. They have learned how to rely on themselves rather than on the institutions and not to have great expectations, but start from scratch easily every time the country or an institution lets them down. Moreover, they are not prone to making permanent connections with companies, but rather voluntarily change them in search for a better job which will give them more satisfaction on a daily basis (Caraher, 2015) or a job which offers higher level of work-life balance (Buzza, 2017).

\subsection{Job Hopping}

Millennials have unique concerns about their career and tend to hold stronger career anchors than members of previous generations (Gong et al., 2018). They keep their resumes updated consequently having a reputation for being job hoppers (Shaw \& Fairhurst, 2008; Meier \& Crocker, 2010). As mentioned, they move freely and frequently from company to company, not being attached to organizations and jobs. They consider it acceptable because they are trying to find out what they want to spend their career doing (Becton, Walker, \& Farmer, 2014; Tulgan, 2009; Smola \& Sutton, 2002), build networks to improve their careers, increase their salary, expand their skill set and expertise. Meier \& Crocker (2010) found that $30 \%$ of Millennials, in a study of 500 , had three jobs in the first eight years of their career. In addition, according to the Gallup report of 2016 on the Millennial generation, $21 \%$ of Millennials in the US say they changed jobs within the year 2015 , which is more than three times the number of non-millennials who report the same (Gallup, 2016). Gallup estimates that millennial turnover costs the U.S. economy $\$ 30.5$ billion annually. These data explain why it is so challenging for the companies to retain them.

One of the aims of this paper is to determine whether the same may be concluded for the Millennials in Serbia. Thus, the following hypothesis was defined:

Hypothesis 1: Millennials intend to change more jobs during their working life than the previous generations.

\subsection{Employee Turnover and Turnover Intentions}

Turnover is defined as the termination of an individual's employment with a company (Tett \& Meyer, 1993; Allen, Bryant \& Vardaman, 2010). In other words, turnover can be described as the rate at which an organization has to replace employees. A high loss percentage should raise a red flag and be a cause for examination to find out why the turnover occurs. 
The turnover intention is defined as an employee's personal intent to leave the organization in the future (Tett \& Meyer, 1993). Although all turnover intentions may not result in actual turnover behaviour, employees' intention to quit the current job represents an important outcome variable (Chang et al., 2013). Moreover, research has consistently shown that it is the most powerful predictor of actual turnover behaviour (e.g., Firth, Mellor, Moore \& Loquet, 2004; Griffeth, Hom \& Gaertner, 2000). Considering that turnover intention accounts for approximately nine to 25 percent of actual turnover (Dalton, Johnson \& Daily, 1999), it is imperative that employers are aware of relevant variables that encourage the growth of turnover intentions.

Numerous authors have researched turnover intentions among Millennials (e.g. George \& Wallio, 2017). Both Ertas (2015) and Kowske, Rasch and Wiley (2013) reported a higher turnover intention rate in the Millennials than in other generations. Also, the data collected by the Talent Edge 2020 survey (Deloitte, 2011) revealed that 26 percent of Millennials were planning to leave the current employer in the following 12 months. Of all generational groups, they were the most likely to develop turnover intentions and look for a new employer in the labour market, while $21 \%$ of Generation X and $17 \%$ of Baby Boomers were more likely to stay with their current company. Furthermore, researchers have found that Millennials also show less willingness to stay in their current jobs than other generations, with the intention to leave their current job within two years or less (Twenge, 2010; Sujansky \& Ferri-Reed, 2009).

Only half of the Millennials - in comparison with $60 \%$ of non-millennials - strongly agree that they plan to be working at their company one year from now; for businesses, this suggests that half of their millennial workforce does not see a future with them (Adkins, 2106). This illustrates the current trend in turnover among Millennials, which will leave gaps in the workforce as the older generations retire (Sujansky \& Ferri-Reed, 2009).

In order to identify the trend among Generation $\mathrm{Y}$ in Serbia, we have tested the following hypothesis:

Hypothesis 2: A Millennial employee is more likely to leave the current employer in the next two years than Baby Boomer or Generation X employees.

\subsection{Job Satisfaction and Turnover Intention}

Organizations have always been struggling to identify the reasons that make an employee leave or intend to leave the job. These issues have been of crucial importance for every company.

Job satisfaction has a direct association with the turnover intention (Brayfield and Crockett, 1955; Vroom, 1964, Spector, 1997). It is often perceived as the strongest indicator of the intention of turnover. Several studies have examined the relationship between job satisfaction and employee turnover intentions (e.g., Ghiselli et al., 2001; McBey and Karakowsky, 2001; Knapp et al., 2017).

Job satisfaction is perceived as the ultimate feeling of people after performing a task. Job satisfaction refers to the extent to which the work meets the basic needs of people, and is consistent with their expectations and values. The level of job satisfaction is often related to different aspects of working practices - e.g., productivity, workplace accidents, absenteeism and turnover.

Research shows that employee turnover can be predicted using comprehensive measures of job satisfaction (Lambert et al., 2001). It is generally accepted that job satisfaction and employee turnover intention are negatively related (Mobley 1977; Susskind et al., 2000), i.e., higher job satisfaction is associated with low employee turnover. Positive, statistically significant relationships have been reported in dozens of studies which compared employees' intentions to leave and actual turnover behaviour (Schwepker, 2001).

However, the majority of these studies were conducted in the US and Canada, and it may be expected that the strength of the relationship between job satisfaction and turnover intentions may vary in different settings. Thus, the following hypothesis was tested in the specific context of Serbia:

Hypothesis 3: Millennials are more likely to leave their job if they are dissatisfied with it.

\section{Methodology}

\subsection{Data Collection and Sample}

The data for this research were collected using a survey method. The research was conducted during 2017 in Serbia. The questionnaire was developed after a comprehensive review of relevant literature related to employee turnover intentions and managing different generations in the modern workplace, mainly focusing 
on the Millennials. The questionnaire was made in the form of an online survey that was distributed by email and posted on social networking websites. The respondents completed the questionnaire without the presence of the authors. The respondents were asked to indicate the extent to which they agree/disagree along a five-point Likert response scale ( $1=$ strongly disagree, $5=$ strongly agree).

In order to provide a sample that will give reliable results a total of 830 responses were received. Among these, the total of valid responses was 802 (which account for $96.6 \%$ of the sample).

The sample included 454 women (56,6\% of the sample) and 348 men (43.4\% of the sample). Viewed by gender, respondents were pretty evenly divided within the generational groups. The majority of the respondents were members of generation $\mathrm{Y}(65.8 \%)$, followed by generation $\mathrm{X}(27.4 \%)$ and $6.7 \%$ were Baby Boomers ${ }^{1}$.

\subsection{Results and Discussion}

The aim of Hypothesis 1 was to determine whether Millennials in Serbia intend to change more jobs during their working life than the previous generation(s). We gathered and compared the responses of the members of different generations, and first tested whether there is a relation between the number of jobs and the generation the respondents belong to, and then compared the numbers. The statistical analysis has shown that there is a statistically significant correlation between the number of jobs they plan to change during their career and the generation which the respondent belongs to $\left(X^{2}=18.423, d f=3, p=0.000\right)$. The largest number of the members of both Generation X and Generation $Y$ expressed an intention to change between 3 and 5 jobs during their working life. However, this percentage declines with the increase of the age of the respondents, i.e., it is smaller for Generation X than for Millennials.

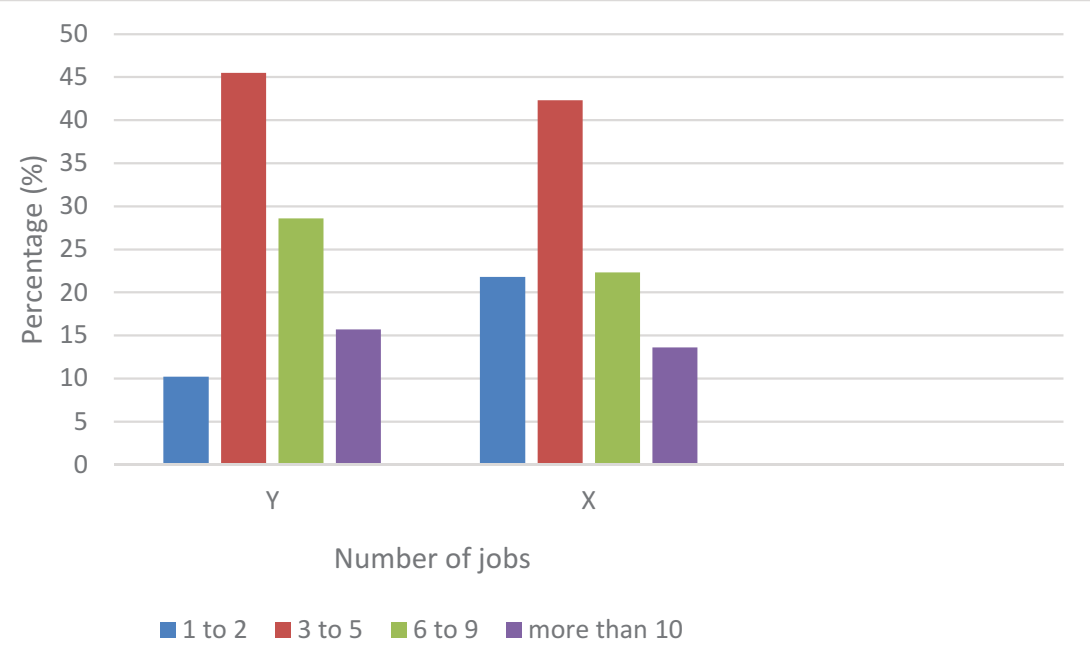

Chart 1: The number of jobs members of Generation Yand X expect to have during their career

In each category, the higher percentage of those who would change 3 to 5 jobs, 6 to 9 jobs, or more than 10 jobs belongs to Generation Y. The only exception is the situation in which the respondents said that they would have one or two jobs in their career. The percentage is much higher for members of generation $\mathrm{X}$ $21.8 \%$, while only $10.2 \%$ of the members of the youngest generation $Y$ stated that they intended to have only one or two jobs during their whole working lives. This finding was to be expected, having in mind that it was common for the members of the previous generations in Serbia to have one job for a lifetime. Therefore, we can conclude that the Millennials tend to change a larger number of jobs in their working life in comparison with members of generation $\mathrm{X}$.

The Baby Boomer generation has just a small percentage of respondents in the sample compared to two other generations. Having this in mind, only descriptive statistics of their responses will be presented. It can be concluded from the chart that an almost equal number of respondents stated that they have changed 1

1The reason for such a low number of Baby Boomer respondents can be explained by the fact that the research was conducted on-line, which resulted in difficulties to gather more responses from this generation. 
to 2 jobs (one third of respondents) or 3 to 5 jobs during their working lives (37\%). This finding is not surprising given that Baby Boomer generation used to be professionally active in the period when changing a job was not considered an advantage in career development and advancement in terms of professional experience.

Having all stated in mind, we can conclude that the intention of the respondents to change a larger number of jobs in their career increases as we move towards the youngest generation in the workplace. Therefore, it may be stated that Hypothesis 1 is corroborated.

In order to examine Hypothesis 2, the respondents were asked about their intention to quit their current job in the next two years, where they were expected to choose an answer from a 5-point Lickert scale (whereby $1=\mathrm{No}, 5=$ Yes). The obtained results were then grouped as presented in the following chart.

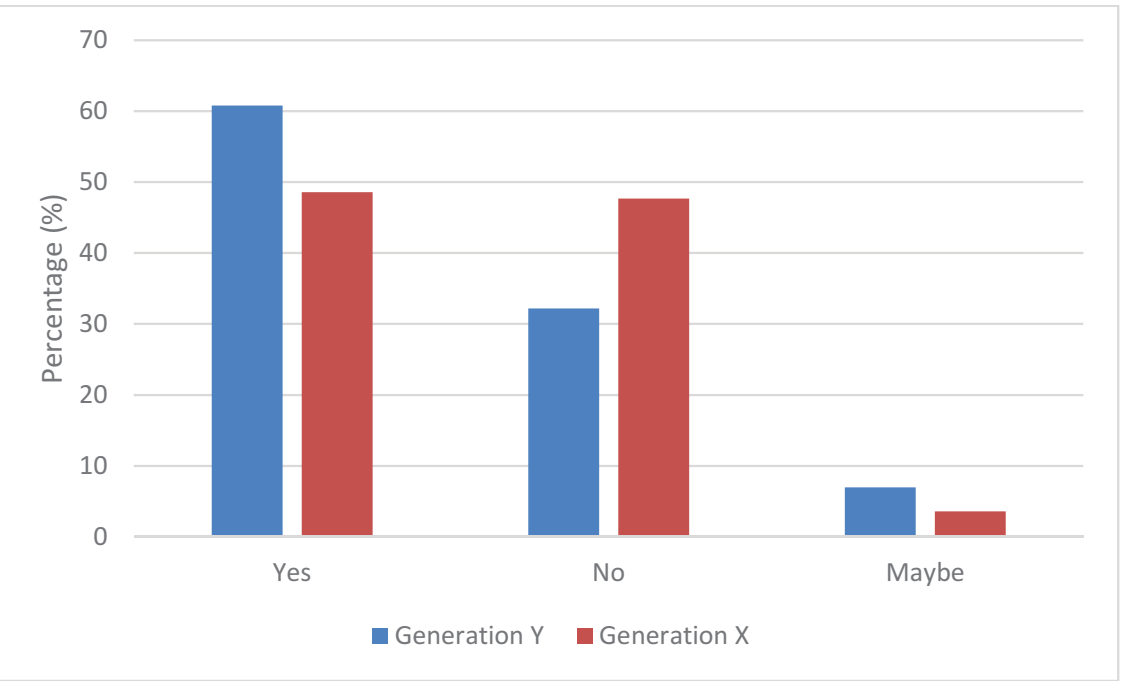

Chart 2: The intention of members of Generations $Y$ and $X$ to quit the current job in the next two years

The respondents were asked to indicate their intention to quit the current job in the next two years on a fivepoint Likert response scale $(1=$ strongly disagree, $5=$ strongly agree). The data were then grouped into three categories. Taking into account the categories of Yes, No and Maybe, and the generational categories $(Y, X)$, the Chi-squared test was carried out. The Chi-squared test results $\left(X^{2}=17.134, d f=2, p=0.000\right)$ indicate that the respondents' intention to quit the current job depends on the generation they belong to.

Substantial differences are noticeable in the responses of the members of different generations. On the one hand, the percentage of those who think that they will quit the job over the next two years significantly increases with the decrease of the respondent's age, from $48.6 \%$ in Generation X to a significant $60.8 \%$ of respondents belonging to Generation Y. On the other hand, the number of those who think they will stay in their current job within the next two years decreases when going towards the youngest generation in the workplace - from $47.7 \%$ in Generation X to $32.2 \%$ in Generation Y. The smallest percentage from both cathegories is of those who are indecisive.

Members of the BabyBoomer generation are not ready to leave the current employer $(72.2 \%$ of respondents) and because of their small number they are not included in the statistics.

Therefore, it can be concluded that the youngest generation is more ready to change the current job in the next two years. These data confirm the previous results, both from this study and from the literature (Caraher, 2015) that Millennials, who grew up during the time of general uncertainty of institutions, are much more ready to change jobs, or, in other words, they have a higher turnover intention rate. Therefore, managers must additionally motivate the members of this generation in order that they shoud prevent their fluctuation. The conclusion is that Hypothesis 2 is supported.

In order to test Hypothesis 3, we examined the relationship between the overall job satisfaction and the intention to quit the job among the members of the Millennial generation. Therefore, we have compared the obtained values of overall job satisfaction with their intention or their plan to change their current job within the next two years. It was proposed that respondents scoring high on job satisfaction will have a lower turnover intention. 
The respondents assessed their overall satisfaction with their current job on a 5 -point Lickert scale $(1=$ completely dissatisfied, $5=$ completely satisfied). The results were then compared with their turnover intentions in the next two years. The results are as presented in Chart 5.

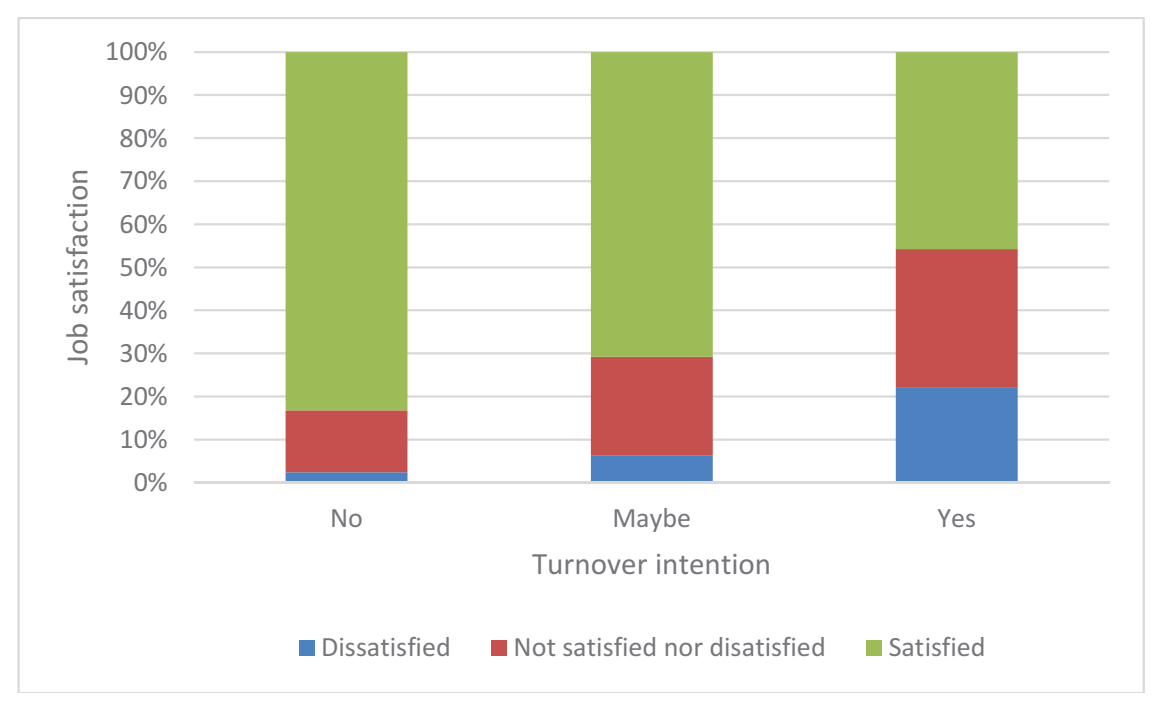

Chart 3: Millennials' job satisfaction as a predictor of their turnover intention

The Chi-square test has confirmed that there is a statistically significant difference between the respondents' job satisfaction and turnover intentions $\left(x^{2}=67,370, d f=4, p=0,000\right)$.

Looking at the chart, the first thing to notice is that the largest percentage of the Millennials are satisfied with their current job and that the smallest percentage of them are dissatisfied. Nevertheless, among those who are planning to change jobs, nearly a quarter $(22.2 \%)$ of them are dissatisfied, while among those who are not planning to change the job, only $2.4 \%$ are dissatisfied. From these data it can be concluded that turnover intention increases with job dissatisfaction - the greater their job satisfaction is, the less likely will the Millennials be to leave their current employer in next two years. Finally, we can draw the conclusion that Hypothesis 3 is supported.

\section{Conclusion}

This research has produced data that support current global trends regarding the connection between the Millennials and the workplace (Lancaster \& Stillman, 2010; Singh, Raj \& Bhandaker, 2012). More precisely, this research has confirmed that Millennials in Serbia plan to have more jobs during their careers than the generations before them. It has also proved that they are more likely to leave their current employers than the Baby Boomer or Generation X employees and that there is a greater chance that they will change their job if they are dissatisfied with it.

Three important pieces of information prove that the same shift in attitude towards the workplace has taken place in Serbia and that the youngest generation of employees demands companies to meet their needs and adjust to them and not vice versa. The misperception of the organizations that Millennials will not impulsively leave their new, stable jobs (Kowske, Rasch \& Wiley, 2013) has proven to be the same in Serbia. Defined by uncertainty and more adapted to change than other generations, just as in other countries (Lancaster \& Stillman, 2010; Zemke, Raines \& Filipczak, 2000), Millennials will not hesitate much before replacing their job for the one that will give them more satisfaction. Nevertheless, it should not be forgotten that certain job satisfaction factors are more important for employees in Serbia than for employees in other countries, due to the specific context of this country (Janicijevic et al., 2015).

To sum up, companies should reconsider their traditional policies and management styles and find different, more constructive ways to work with Generation Y. By satisfying their needs, companies will be more successful at retaining soon to be the most numerous generation in the workplace, thus ensuring the future of their own businesses.

The main limitation of the paper refers to a small percentage of respondents belonging to Baby Boomer generation in our sample, due to the fact that it was difficult to reach them through an online survey. Further research in this area may aim at gathering more responses from this generation, but through a paper-based survey rather than an online one. 


\section{REFERENCES}

[1] Allen, D., Bryant, P., \& Vardaman, J. (2010). Retaining talent: Replacing misconceptions with evidenced based strategies. Academy of Management Perspectives, 48-64.

[2] Adkins, A. (2016). Millennials: The Job-Hopping Generation, May 12, 2016, http://news.gallup.com/businessjournal/191459/millennials-job-hopping-generation.aspx

[3] Barnard, R. (1998). Chips and Pop: Decoding the Nexus Generation. Toronto: Malcom Lester, Canada.

[4] Becton, J. B., Walker, H. J.,\& Jones-Farmer, A. (2014). Generational Differences in Workplace Behavior. Journal of Applied Social Psychology, 44(3), 175-189.

[5] Brayfield, A.H. \& Crockett, W. H. (1955). Employee Attitude and Employee Performance, Psychological Bulletin, 52(5), 396-424.

[6] Buzza, J. S. (2017). Are You Living to Work or Working to Live? What Millennials Want in the Workplace. Journal of Human Resources, 5(2), 15-20. DOI: 10.15640/jhrmls.v5n2a3

[7] Caraher, L. (2015). Millennials \& Management: The Essential Guide to Making It Work at Work, Brookline: Biblimotion, Inc., USA.

[8] Chang, W. J. A., Wang, Y. S., \& Huang, T. C. (2013). Work design-related antecedents of turnover intention: A multilevel approach. Human Resource Management, 52(1), 1-26.

[9] Ciarniene, R., \& Vienazindiene, M. (2018). Flexible Work Arrangements from Generation and Gender Perspectives: Evidence from Lithuania. Engineering Economics, 29(1), 84-92. http://dx.doi.org/10.5755/j01.ee.29.1.19247

[10] Dalton, D. R., Daily, C. M., Johnson, J. L.,\& Ellstrand, A. E. (1999). Number of directors and financial performance: A meta-analysis. Academy of Management Journal, 42(6), 674-686.

[11] Deal, J. J., Altman, D. G.,\& Rogelberg, S. G. (2010). Millennials at work: What we know and what we need to do (if anything). Journal of Business and Psychology, 25, 191-199. http://dx.doi.org/10.1007/s10869-010-9177-2

[12] Deloitte (2011). Talent Edge 2020: Building the recovery together - What talent expects and how managers are responding. Retrieved from http://www.deloitte.com/assets/DcomUnitedStates/Local\%20Assets/Documents/IMOs/Talent/us_talent_talentedge2020employee_042811.pdf

[13] dos Reis, J. A. F., \& Ramos, S. C. (2018). Cognition of a successful professional: a study on the mental constructs of millennials. Revista Brasileira de Estratégia, 11(1), 166.

[14] Ertas, N. (2015). Turnover intentions and work motivations of millennial employees in federal service. Public Personnel Management, 44(3), 401-423. https://doi.org/10.1177/0091026015588193

[15] Firth, L., Mellor, D., Moore, K. A.,\& Loquet, C. (2004). How can managers reduce employee turnover intention?. Journal of Managerial Psychology, 19(2), 170-187.

[16] Gallup (2016) How Millennials Want to Work and Live http://news.gallup.com/reports/189830/e.aspx

[17] George, J., \& Wallio, S. (2017). Organizational justice and millennial turnover in public accounting. Employee Relations, 39(1), 112-126. https://doi.org/10.1108/ER-11-2015-0208

[18] Ghiselli, R., La Lopa, J.M.,\& Bai, B., (2001). Job satisfaction, Life satisfaction \& turnover intention of food service managers. Cornell Hotel \& Restaurant Administration Quarterly.42, 28-37.

[19] Gong, B., Ramkissoon, A., Greenwood, R. A., \& Hoyte, D. S. (2018). The Generation for Change: Millennials, Their Career Orientation, and Role Innovation. Journal of Managerial Issues, 30(1), 82-96.

[20] Griffeth, R. W., Hom, P. W., \& Gaertner, S. (2000). A meta-analysis of antecedents and correlates of employee turnover: Update, moderator tests, and research implications for the next millennium. Journal of Management, 26(3), 463-488.

[21] Hammill, G. (2005). Mixing and managing four generations of employees. Retrieved from fdu.edu:www.fdu.edu/newspubs/magazine/05ws/generations.htm

[22] Inglehart, R. (1997). Modernization and Postmodernization: Cultural, Economic, and Political Change in 43 Societies. Princeton: Princeton University Press, New Jersey.

[23] Ivancevic, S. \& Ratkovic, T. (2016). Millennials in the Workplace, Proceedings of XV International Symposium, "Reshaping the Future through Sustainable Business Development and Entrepreneurship", SymOrg 2016, Faculty of Organizational Sciences, Zlatibor,June 2016, ISBN 9788676803262,733-736

[24] Janicijevic, N., Kovacevic, P., \& Petrovic, I. (2015). Identifying organizational factors of job satisfaction: The case of one Serbian company. Economic annals, 60(205), 73-104. DOI:10.2298/EKA1505073J

[25] Knapp, J. R., Smith, B. R., \& Sprinkle, T. A. (2017). Is it the job or the support? Examining structural and relational predictors of job satisfaction and turnover intention for nonprofit employees. Nonprofit and Voluntary Sector Quarterly, 46(3), 652-671. https://doi.org/10.1177/0899764016685859

[26] Kovacevic, I., \& Labrovic, J. A. (2018). Work motivation among millennial employees with different life goals: Case of Serbian companies. Revista Brasileira de Estratégia, 11(1), 3. DOI: http://dx.doi.org/10.7213/rebrae.v11i1.23369.g22513 
[27] Kowske, B., Rasch, R.,\&Wiley, J. (2013). Millennials' lack of attitude problem: An empirical examination of generational effects on work attitudes. Journal of Business Psychology, 25(2), 265-279. DOI: 10.1007/s10869-010-9171-8

[28] Lambert, E. G., Hogan, N.L.,\& Barton, S. M. (2001). The impact of job satisfaction on turnover intent: a test of a structural measurement model using a national sample of workers. The Social Science Journal, 38(2), 233-250. doi:10.1016/S0362-3319(01)00110-0

[29] Lancaster, L. \& Stillman, D. (2010). The M-factor. New York, NY: HarperCollins Publishers.

[30] McBey, K. \& Karakowsky, L. (2001). Examining sources of influence on employee turnover in the part-time work context. Career Development International, 6(1),39-48.

[31] Meier, J. \& Crocker, M. (2010). Generation Y in the workforce: Managerial challenges. The Journal of Human Resource and Adult Learning, 6(1), 68-78.

[32] Mobley, W. (1977). Intermediate linkages in the relationship between job satisfaction and employee turnover. Journal of Applied Psychology, 62, 237-240.

[33] Ng, E., \& Schweitzer, L. (2010). New generation, great expectations: A field study of the millennial generation. Journal of Business Psychology, 25(2), 281-292. DOI: 10.1007/s10869-010-9159-4

[34] Olson, P., \& Brescher, H. (2011). The power of 4 the four generations: Who they are. Indianapolis: Adayana.

[35] Schwepker, C. H. (2001). Ethical climate's relationship to job satisfaction, organizational commitment, and turnover intention in the salesforce, Journal of Business Research, 54(1),39-52

[36] Shaputis, K. (2004). The Crowded Nest Syndrome: Surviving the Return of Adult Children. Olympia: Clutter Fairy Publishing, USA.

[37] Shaw, S., \& Fairhurst, D. (2008), 'Engaging a New Generation of Graduates,' Education and Training, 50, 366-378.

[38] Singh, P., Raj, S., \& Bhandaker, A. (2012). Millennials and the Workplace : Challenges for Architecting the Organizations of Tomorrow. New Delhi: SAGE Publications India Pvt., Ltd., India.

[39] Smola, K.W., \& Sutton, C.D. (2002). Generational Differences: Revisiting Generational Work Values for the New Millennium, Journal of Organizational Behavior, 23, 363-382.

[40] Spector, P. (1997). Job Satisfaction: Application, Assessment, Causes and Consequences. Thousand Oaks, CA. Sage Publications.

[41] Sujansky, J., \& Ferri-Reed, J. (2009). Keeping the Millennials. Hoboken, NJ: Wiley and Sons.

[42] Susskind, A.M., Borchgrevink, C.P., Kacmar, K.M., \& Brymer, R.A.. (2000). Customer service employees' behavioral intentions and attitudes: An examination of construct validity and a path model. International Journal of Hospitality Management, 19 (1), 53-77.

[43] Tett, P., \& Meyer, J. (1993). Job satisfaction, organizational commitment, turnover intention and turnover: Path analysis based on metaanalytic findings. Journal of Personnel Psychology, 46(2), 259-293. https://doi.org/10.1111/j.1744-6570.1993.tb00874.x

[44] Tulgan, B. (2015). Bridging the Soft Skills Gap: How to Teach the Missing Basics to Today's Young Talent. New Jersey: John Wiley \& Sons, Inc., Hoboken, NJ.

[45] Twenge, J. M. (2010). A review of the empirical evidence on generational differences in work attitudes. Journal of Business Psychology, 25(2),201-210.

[46] Vroom, V.H. (1964), Work and Motivation, New York: Wiley.

[47] Zemke, R., Raines, C., \& Filipczak, B. (2000). Generations at work: Managing the clash of veterans, boomers, xers, and nexters in your workplace. New York, NY: American Management Association.

[48] Zemke, R., Raines, C., \& Filipczak, B. (2013). Generations at Work: Managing the Clash of Boomers, Gen Xers, and Gen Yers in the Workplace (2nd ed.). New York: AMACOM, USA.

[49] Zhezhu, W., Jaska, P., Brown, R., \& Dalby, B. (2010). Selecting Communication Media In A MultiGenerational Workplace. International Journal of Business \& Public Administration, 7(2), 134-150.

Received: 2018-05-12

Revisions requested: 2018-06-04

Revised: 2018-06-15

Accepted: 2018-08-30 


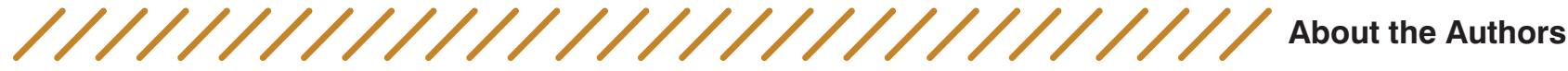

\section{Tatjana Ivanović \\ University of Belgrade, Faculty of Organizational Sciences, Serbia tatjana.ivanovic@fon.bg.ac.rs}

Tatjana Ivanovic is an Assistant Professor of Human Resource Management at the Faculty of Organizational Sciences. She holds a PhD degree in Human Resource Management as well as a MSc degree in Public Management from the SDA Bocconi, Italy. She has worked at the Faculty of Organizational Sciences since 2007, teaching different subjects in the field of Human Resource Management and International Human Resource Management at undergraduate and master studies.

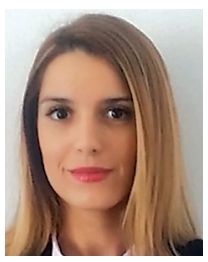

Sonja Ivančević

Primary School 'Starina Novak', Belgrade, Serbia sonja.ivancevic@yahoo.com

Sonja Ivančević has an M.A. in Human Resources Management from the Faculty of Organizational Sciences and a B.A. in English Language and Literature. She works as a teacher, but has also been engaged in a variety of HR activities, such as recruitment, selection, creating and conducting training programmes and so on. She does research

in the fields of employee motivation, generational differences in the workplace and burnout syndrome. She is the author of the accredited professional development seminar 'Burnout Syndrome - How to Survive Stress in the Workplace'. 